\title{
A method for the determination of human chorionic gonadotrophin in urine extracts
}

\author{
P. G. LYNCH AND HERTA SCHWABACHER
}

From Group 9 Laboratory, Peace Memorial Hospital, Watford, Herts.

SYNOPSIS A method is described for the preparation in rabbits of a specific antiserum to human chorionic gonadotrophin. The ability of this antiserum to fix complement in the presence of urinary human chorionic gonadotrophin is demonstrated. The standardization of antiserum against the international standard preparation of human chorionic gonadotrophin, the determination of antiserum specificity using appropriate controls, and the value of antiserum in the diagnosis of pregnancy and conditions associated with high urinary levels of human chorionic gonadotrophin is emphasized.

By the complement-fixation test it is possible to detect a minimum of 1.5 international units of human chorionic gonadotrophin contained in $0.1 \mathrm{ml}$. of a 1 in 2 dilution of urine extract. In the Hogben pregnancy test, using $2.5 \mathrm{ml}$. of urine extract per animal, a minimum concentration of 70 international units of human chorionic gonadotrophin is required to give a positive response. The ease and economy of the complement-fixation test are described and results are compared with those of the Hogben test.

PREPARATION OF HUMAN CHORIONIC
GONADOTROPHIN ANTISERUM

Human chorionic gonadotrophin is a mucopolysaccharide of molecular weight 100,000 (Gurin, Bachman, and Wilson, 1940) and might, therefore, be suitably antigenic. At the present time no chemically pure preparation of this hormone exists, a fact which must obviously complicate the issue from an immunological standpoint. Two commercial preparations of human chorionic gonadotrophin having a high degree of chemical purity were selected as antigens. These preparations were Pregnyl (Organon) and H.C.G. (Leo). Female rabbits weighing approximately 2,000 to $3,000 \mathrm{~g}$. were used as test animals.

Various immunizing procedures were adopted (Table I). Either Pregnyl or H.C.G. (Leo) was used as antigen admixed with Ramon's adjuvant or Freund's complete adjuvant. Aluminium phosphate was used as adjuvant on four occasions but was found to be unsatisfactory. One thousand five hundred international units of antigen (H.C.G.) well mixed with adjuvant were administered subcutaneously at fortnightly or monthly intervals. The optimum number of injections required to produce antiserum varied in most cases from two to six. In six rabbits, antigen was also administered by the intravenous route. This procedure did not appear to confer any

Received for publication 17 June 1963 advantage over the subcutaneous route alone and the intravenous route was subsequently abandoned. ${ }^{1}$

\section{TITRATION OF HUMAN CHORIONIC GONADOTROPHIN ANTISERUM}

The test rabbits were bled from an ear vein at weekly intervals commencing two weeks after the first injection of antigen (H.C.G.). Test bleeds should not be undertaken earlier than six days after any injection of antigen (H.C.G.). The sera were separated from the clotted blood samples and each serum was heated at $56^{\circ} \mathrm{C}$. for 30 minutes to inactivate complement. Doubling dilutions of test sera were made in normal saline and $0.1 \mathrm{ml}$. volumes of these dilutions were titrated against 0.1 $\mathrm{ml}$. amounts of a human chorionic gonadotrophin solution (Department of Biological Standards) used at a strength of 1.5 international units in $0.1 \mathrm{ml}$. normal saline. Fresh pooled guinea-pig serum was used as a source of complement. Throughout the test, complement was used at 3 minimal haemolytic doses (3.M.H.D.) strength and $0.1 \mathrm{ml}$. volumes of this dilution of complement were used. A $2 \%$ suspension of sensitized sheep red cells was used as the haemolytic system. The antisera under test, complement, and antigen were mixed and incubated at $37^{\circ} \mathrm{C}$. for one hour. At the end of this time

${ }^{1}$ Since the submission of this article for publication we have obtained satisfactory human chorionic gonadotrophin antiserum using the intramuscular technique of Fulthorpe et al. (1963). 
$0.2 \mathrm{ml}$. volumes of the $2 \%$ sensitized sheep red cell suspension were added to each tube and after further incubation at $37^{\circ} \mathrm{C}$. for 30 minutes readings were made. Any serum yielding a titre of 1 in 8 or more was considered to be satisfactory. It is most important that those animals giving satisfactory antiserum titres should be bled out on the same day as the test bleed. After anaesthetization, blood was collected by sterile cardiac puncture from suitable rabbits. Our experience is that undue delay between the test bleed and the final bleeding out can result in complete loss of antibody or occasionally in the development of sheep red cell haemolysins. Blood obtained from rabbits showing satisfactory anti-human chorionic gonadotrophin titres was allowed to clot and serum was separated from the resulting clot by centrifugation. The serum was heated at $56^{\circ} \mathrm{C}$. for 30 minutes to inactivate complement and was then divided into $1 \mathrm{ml}$. aliquots and stored without preservative in sealed hard glass ampoules at $-20^{\circ} \mathrm{C}$. It is necessary to store the samples in this way for the following reasons:-1 It has been established that too frequent freezing and thawing of large volumes of antiserum causes marked deterioration in antibody potency. 2 Only small quantities of antiserum are required for each batch of tests. 3 If frozen antiserum is kept in screw-cap containers, $\mathrm{CO}_{2}$ used for the purposes of refrigeration or air from the atmosphere is able to seep through the junction of cap and bottle. This has been shown to result in progressive deterioration in the potency of the sample.

PROPERTIES OF A SATISFACTORY ANTI-HUMAN CHORIONIC GONADOTROPHIN SERUM A satisfactory anti-human chorionic gonadotrophin serum for use in complement-fixation tests involving pregnancy urine extracts prepared by the Scott technique (1940) must fulfil the following conditions.

1 It must be able to fix a minimum of 1.5 international units of human chorionic gonadotrophin per $0 \cdot 1 \mathrm{ml}$. urine extract. The reason for this is twofold. First, in the Hogben test it is customary to inject $2.5 \mathrm{ml}$. of urine extract prepared by the Scott technique into a Xenopus laevis toad weighing 60 to $100 \mathrm{~g}$. It has been repeatedly found that a satisfactory animal of this weight will respond to a minimum of 70 international units of human chorionic gonadotrophin, i.e., $2 \cdot 8$ international units per $0.1 \mathrm{ml}$. urine extract. In the second instance it was found preferable to dilute the urine extracts 1 in 2 with barbitone complement-fixation test diluent ${ }^{1} \mathrm{pH} \mathbf{7 \cdot 2}$ before examination by the complement-fixation test, as many of the undiluted urine extracts had anticomplementary properties. In most cases the anticomplementary effects were abolished at the 1 in 2 dilution.

2 It must give no complement-fixation with urine extracts prepared by the Scott technique from human adult males or from non-pregnant, non-menopausal adult females.

3 It must have no anticomplementary properties.

4 It must neither agglutinate nor haemolyse sensitized sheep red cells.

${ }^{1}$ Barbitone C.F.T. diluent can be obtained from Oxo Ltd., London.

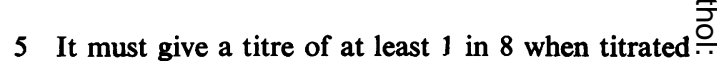
against the international standard preparation of human $\vec{F}$ chorionic gonadotrophin used at a strength of 1.5 international units per $0.1 \mathrm{ml}$. normal saline.

6 It must remain stable when sealed in hard glass ampoules $^{1}$ in $1 \mathrm{ml}$. amounts at a temperature of $-20^{\circ} \mathrm{C}$.

\section{RESULTS OF IMMUNIZING PROCEDURES \\ IN THE PREPARATION OF HUMAN CHORIONIC GONADOTROPHIN ANTISERUM}

Twenty-four rabbits in the series were inoculated $\stackrel{\vec{\omega}}{\circ}$ with antigen and adjuvant as described in the text.용 The results obtained are set out in Table I. Reference to Table I shows the difficulties of preparing a specific anti-human chorionic gonadotrophin serum is of suitable potency. In view of the low molecular of weight and of the impurities in commercial prepara- $\frac{O}{2}$ tions this is not surprising.

Failure to obtain satisfactory antisera from rabbits $\bar{Z}$ 16 and 21 was due to delay between the test bleed and the final bleeding out. During the period of delay, a powerful sheep red cell haemolysin had developed ${ }_{\mathbb{\Phi}}$ in both antisera. As already emphasized, it is most important, therefore, to bleed out any animal whose $\vec{\mathscr{}}$ serum shows a satisfactory titre on the same day and within a few hours of the test bleed.

A method for the further chemical purification of commercial preparations of human chorionic $\frac{D}{0}$ gonadotrophin and of urine extracts has been described by Butt and Round (1958). Further puri- $\stackrel{\AA}{\perp}$ fication of human chorionic gonadotrophin used for immunization or of urine extracts containing human chorionic gonadotrophin was not adopted in the present work. The antigenicity of human chorionic gonadotrophin might be improved if it were possible to conjugate it to a suitable protein. This procedure, however, could well result in the production of interfering antibodies in the test animals and complex absorption experiments would then be required for the removal of these non-specific components.

\section{ESTIMATION OF URINARY HUMAN CHORIONIC GONADOTROPHIN}

In the diagnosis of pregnancy, an early morning specimen $N$ of urine, of at least $100 \mathrm{ml}$. by volume, is extracted by $\mathrm{N}$ the Scott technique. The resulting extract is carefully $N$ neutralized and $0 \cdot 1 \mathrm{ml}$. is diluted 1 in 2 with barbitone $\omega$ complement-fixation test diluent ${ }^{2}$ at $p H \mathbf{H} 7 \cdot 2$. Volumes,each $\underset{<}{\sigma}$ of $0.1 \mathrm{ml}$., of the diluted extract are placed into each of two Wassermann reaction $3 \times \frac{3}{8}$ in. tubes. To one tube $\mathbb{D}$ is then added $0.1 \mathrm{ml}$. 3M.H.D. complement plus $0.1 \mathrm{ml}$. $\stackrel{?}{+}$ anti-human chorionic gonadotrophin serum used at its predetermined optimum titre. To the other tube is added

${ }^{2}$ Hard glass ampoules for storing small volumes of antisera can be obtained from Henry Bush and Co. Ltd., Waddon Factory Estate, Croydon, Surrey.

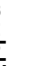

.

(1)


TABLE I

RESULTS OF IMMUNIZING RABBITS WITH HUMAN CHORIONIC GONADOTROPHIN

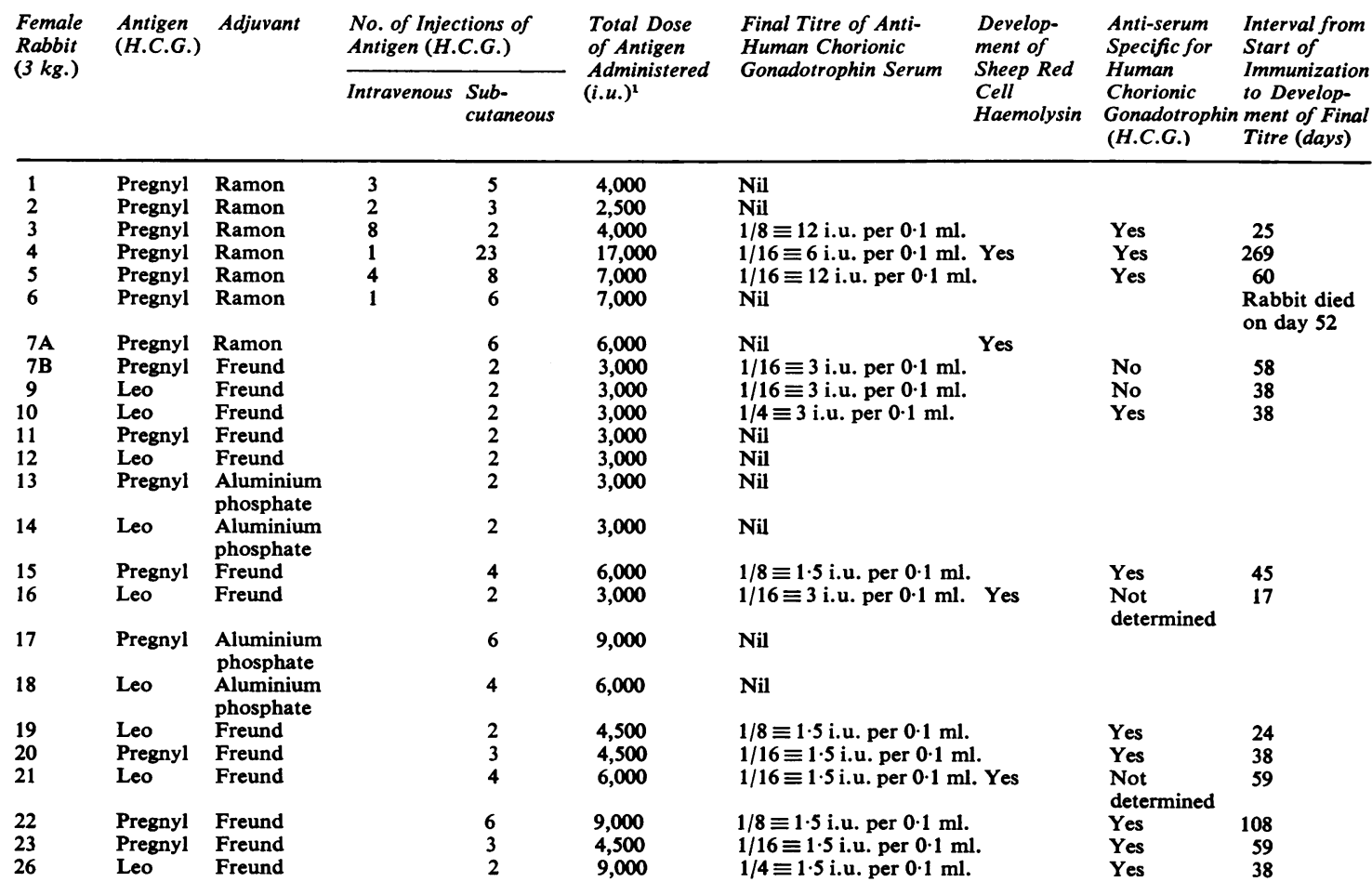

${ }^{1}$ International units as stated by the manufacturers.

$0 \cdot 1 \mathrm{ml}$. 3M.H.D. complement plus $0 \cdot 1 \mathrm{ml}$. diluent. Known positive and negative control urine extracts are put up at the same time as the test series. All tubes are incubated at $37^{\circ} \mathrm{C}$. for one hour. At the end of this time $0.2 \mathrm{ml}$. volumes of a $2 \%$ suspension of sensitized sheep red cells are added to each tube and after further incubation at $37^{\circ} \mathrm{C}$. for 30 minutes readings are made. A positive reading is given by those tubes showing no lysis of the red cells and a clear supernatant. A supernatant showing haemolysis indicates a negative result. Any urine extracts showing anticomplementary activity should be discarded and a fresh early morning specimen of urine requested.

In the quantitative determination of human chorionic gonadotrophin the procedure adopted is exactly as described above with the difference that doubling dilutions of the urine extract in barbitone complement-fixation test diluent are required. The end-point is taken as the highest dilution tube showing a clear supernatant. Readings may be simplified by centrifugation of the tubes at the end of the test.

ANTICOMPLEMENTARY PROPERTIES OF CERTAIN URINE EXTRACTS In our early experiments it was soon discovered that a large number of extracts of neat urine prepared by the Scott technique were anticomplementary. This difficulty appeared at first to have been resolved by diluting the urine extracts 1 in 2 with barbitone complement-fixation test diluent. Since the publication of our preliminary communication (Lynch and Schwabacher, 1962), we have encountered a very small but appreciable number of urine extracts which showed anticomplementary activity even at a 1 in 2 dilution (Table II). Such extracts are quite unsuitable for examination and should be discarded.

\section{TABLE II}

ANTICOMPLEMENTARY PROPERTIES OF URINE EXTRACTS

No. of Undiluted Urine
Extracts Tested

67
No. of Undiluted Urine Extracts Anticomplementary
No. of Urine Extracts Diluted 1 in 2 with Buffer Diluent
No. of Urine Extracts Diluted

1 in 2 Anticomplementary 
Attempts were also made to abolish anticomplementary effects by treating affected urine extracts with the solvent Arcton 113. This proved unsatisfactory because it was established that human chorionic gonadotrophin passes into the solvent phase. The anticomplementary effects shown by these urine extracts may well be accounted for when it is appreciated that there is often a considerable delay from the time of collection of an early morning specimen of urine to its eventual extraction. Transit in the post is most favourable to bacterial multiplication in urine specimens. It is therefore important to test the urine extracts for human chorionic gonadotrophin activity as soon as possible after extraction. If this is impracticable the urine extracts should be stored for not more than 48 hours at 0 to $2^{\circ} \mathrm{C}$. before testing. In our preliminary communication we reported that there seemed to be no appreciable loss of human chorionic gonadotrophin activity in extracts of neat urine kept at this temperature for as long as seven days. Although this proviso still holds, anticomplementary affects frequently prove troublesome in stored extracts.

\section{IMMUNODIFFUSION OF HUMAN CHORIONIC GONADOTROPHIN ANTISERUM}

The method of Elek (1948) and Ouchterlony (1949) and the micro-method of May and Rawlins (1962) using ion agar were used in a number of experiments. Specific anti-human chorionic gonadotrophin sera failed consistently to yield precipitin lines against known Hogben-positive urine extracts or against various concentrations of standard human chorionic gonadotrophin in normal saline. Certain anti-human chorionic gonadotrophin sera which at first appeared satisfactory in the complement-fixation test were later discovered to fix complement when tested against known Hogben-negative male and female urine extracts. These non-specific antisera yielded precipitin lines against Hogben-positive urine extracts but failed to yield precipitin lines against various concentrations of the standard human chorionic gonadotrophin preparation. Such false positive reactions may be due to union of a mucoprotein in the urine extracts with a non-specific antibody in the anti-human chorionic gonadotrophin serum. Reference to Table I shows that antisera from rabbits $7 B$ and 9 had non-specific properties. An attempt to remove these non-specific reactions by the method of Brody and Carlström (1962) was successful. Titrations of non-specific antiserao saturated with an equal volume of serum taken from흘 a non-pregnant, non-menopausal subject failed to $\frac{\bar{s}}{\frac{1}{2}}$ give false positive reactions with Hogben-negative $\stackrel{\mathbb{D}}{\Omega}$ male and female urine extracts.

\section{DISCUSSION}

The complement-fixation test may be used as ao qualitative determination of urinary human chorionic $-\overrightarrow{-}$ gonadotrophin in pregnancy and as a quantitative determination of urinary human chorionic gonado-cr trophin in clinical conditions associated with a highơ urinary output of human chorionic gonadotrophin응 e.g., hydatidiform mole, chorion epithelioma, andin Rhesus-negative mothers bearing severely affected $Z$ Rhesus-positive infants (Scott, 1958).

It is interesting to compare the accuracy of the $\frac{\Phi}{3}$ complement-fixation test with the Hogben test in pregnancy Reference to the table (Table III) shows close agreement of results in the small series of parallel studies undertaken. The main difficulty in the clinical application of the complement-fixation test lies in the production of human chorionic gona-s dotrophin antiserum of suitable potency and of suitable specificity. In connexion with the immuniz-气ू ing procedure it should be remembered that injec- $-\stackrel{\mathbb{\Omega}}{\Omega}$ tions at long intervals with human chorionic gonado- $\overrightarrow{\vec{O}}$ trophin plus Freund's adjuvant give better results 3 than repeated injections at short intervals. The course of injections should be relatively short so as? to minimize the development of secondary antibodies and sheep red cell haemolysins.

In the clinical application of the complement $-\frac{5}{3}$ fixation test the obvious disadvantage of the methodi is the large percentage of urine extracts $(4.5 \%$ in the present series) showing pronounced anticomple- 0 mentary activity. Such anticomplementary activity? is largely due to delay in collection and extraction of the urine samples which tends to favour bacteria multiplication. If, therefore, the method is to bes adopted by routine laboratories the collection and extraction of urine specimens would preferably be done on the same day.

TABLE III

COMPARISON OF COMPLEMENT-FIXATION TEST WITH HOGBEN TEST

\begin{tabular}{|c|c|c|c|c|c|c|c|}
\hline \multirow{2}{*}{$\begin{array}{l}\text { Total No. of } \\
\text { Urine Extracts } \\
\text { Examined }\end{array}$} & \multicolumn{2}{|c|}{ Hogben Test } & \multicolumn{3}{|c|}{ Complement-fixation Test } & \multirow{2}{*}{$\begin{array}{l}\text { False Positive } \\
\text { Result in Com- } \\
\text { plement-fixation } \\
\text { Test }\end{array}$} & \multirow{2}{*}{$\begin{array}{l}\text { False Negative } \\
\text { Result in Com- } \\
\text { plement-fixation } \\
\text { Test }\end{array}$} \\
\hline & Positive & Negative & Positive & Negative & $\begin{array}{l}\text { Anti- } \\
\text { complementary }\end{array}$ & & \\
\hline
\end{tabular}

140

64

76

61

72

7 
The advantages of the complement-fixation test over the Hogben test are as follows:-1 The test is easy to perform and the results can be obtained on the day of the test. If there is no urgency for results, the test can be run in parallel and on the same day as the Wassermann reactions. More than 100 tests can can be completed with ease in a morning. 2 No animals are required with a resulting saving in technical staff and materials. 3 The test can be adapted to yield quantitative results with a much more satisfactory and reliable end-point than can be obtained by present-day bio-assay methods. 4 Facilities are available in all laboratories for the preparation of anti-human chorionic gonadotrophin sera.

We are indebted to Dr. D. R. Bangham of the National
Institute for Medical Research, London, for supplying us with the international standard preparation of human chorionic gonadotrophin.

\section{REFERENCES}

Brody, S., and Carlström, G. (1962). Ciba Foundation Colloquium on Endocrinology, 14, 329.

Butt, W. R., and Round, B. P. (1958). J. Endocr., 17, 75.

Elek, S. D. (1948). Brit. med. J., 1, 493.

Fulthorpe, A. J., Tovey, J. E., Parke, J. A. C., and Monckton, J. C. (1963). Ibid., 1, 1049.

Gurin, S., Bachman, C., and Wilson, D. W. (1940). J. biol. Chem., 133, 467.

Lynch, P. G., and Schwabacher, H. (1962). Nature (Lond.), 195, 246.

May, J. R., and Rawlins, G. A. (1962). J. clin. Path., 15, 186.

Ouchterlony, O. (1949). Lancet, 1, 346.

Scott, J. S. (1958). J. Obstet. Gynaec. Brit. Emp., 65, 689.

Scott, L. D. (1940). Brit. J. exp. Path., 21, 320.

\section{The September 1963 Issue}

\section{THE SEPTEMBER 1963 ISSUE CONTAINS THE FOLLOWING PAPERS}

Pioneer work by Professor Dudgeon in cytological diagnosis J. BAMFORTH

Exfoliative cytology in the diagnosis of cancer of the bronchus S. W. A. KUPER

Progressive multifocal leucoencephalopathy and primary hypersplenism With a note on the association between disease of the reticuloendothelial system and progressive multifocal leucoencephalopathy v. F. WEINSTEIN, A. L. WOOLF, and M. J. MEYNELL

Diffuse degeneration of cerebral white matter resembling so-called Binswanger's disease and symmetrical necrosis of the globus pallidus associated with acute porphyria and cerebral atherosclerosis w. THOMAS SMITH and S. R. F. WHITTAKER

Disseminated herpes simplex in newborn infants $T$. BIRD, J. E. ENNIS, A. J. WORT, and P. S. GARDNER

Chronic myeloid leukaemia with lymphosarcoma J. s. HOWELL, and A. G. W. WHITFIELD

Two cases of thrombohaemolytic thrombocytopenic purpura associated with changes in red cell morphology P. MCCORMACK, D. J. O'BRIEN, and R. A. M. OLIVER

A thrombocyte consumption test for the demonstration of autoantibody-like serum factors GY. DóBIÁS

The thymus in hepatic cirrhosis MAURICE CORRIDAN Renal biopsy in a general hospital PAUL TURNER

Nasal carriage of staphylococci and post-operative staphylococcal wound infection R. J. HENDERSON and R. E. O. WILliams
The clumping of Staphylococcus pyogenes by serum and fibrinogen-free plasmas. A. E. BROWN and A. A. FARUQUE

Relationships of coagulases and agglutinins in vitro and in vivo to Staphylococcus pyogenes A. HENDERSON and J. BRODIE

Cryptococcal meningitis in Hong Kong C. T. HUANG, P. C. WONG, and C. H. CHAN-TEOH

The estimation of blood galactose using a glucose oxidase-catalase reagent C. H. BOWDEN

A rapid colorimetric method for the estimation of urinary chlorides R. A. CROCKSON

Technical and experimental errors in the spectrophotometric determination of oxygen saturation R. G. FISH and M. RADCLIFFE LEE

Obituary: Dr. J. L. Pinniger

The planning of benching and services for the modern pathological laboratory K. M. LAURENCE

\section{Technical methods}

Thin-layer chromatography for amino-acids and sugars D. N. BARON and J. ECONOMIDIS

The reliability of the Albustix test for proteinuria M. R. WILLS and G. K. MCGOWAN

The effect of citrate preservatives on estimating the Westergren method of erythrocyte sedimentation rates H. STERNDALE

Fixation and transport in a postal cytodiagnostic service J. A. HIGGINS and J. P. SMITH

Book reviews

Copies are still available and may be obtained from the PUBLISHING MANAGER, BRITISH MEDICAL ASSOCIATION, TAVISTOCK SQUARE, W.C.I., price 18s. 6D. 